\title{
High-throughput sequencing revealed differences of microbial community structure and diversity between healthy and diseased Caulerpa lentillifera
}

Zhourui Liang ${ }^{1,2}$, Fuli Liu ${ }^{1,2^{*}}$, Wenjun Wang ${ }^{1,2}$, Pengyan Zhang ${ }^{1,2}$, Xiutao Sun ${ }^{1,2}$, Feijiu Wang ${ }^{1,2}$ and Heather Kell ${ }^{3}$

\begin{abstract}
Background: Caulerpa lentillifera is one of the most important economic green macroalgae in the world. Increasing demand for consumption has led to the commercial cultivation of C. lentillifera in Japan and Vietnam in recent decades. Concomitant with the increase of $C$. lentillifera cultivation is a rise in disease. We hypothesise that epiphytes or other microorganisms outbreak at the C. lentillifera farm may be an important factor contributing to disease in C. lentillifera. The main aims are obtaining differences in the microbial community structure and diversity between healthy and diseased C. lentillifera and key epiphytes and other microorganisms affecting the differences through the results of high-throughput sequencing and bioinformatics analysis in the present study.

Results: A total of 14,050, 2479, and 941 operational taxonomic units (OTUs) were obtained from all samples using $16 \mathrm{~S}$ rDNA, 18S rDNA, and internal transcribed spacer (ITS) high-throughput sequencing, respectively. 16S rDNA sequencing and 185 rDNA sequencing showed that microbial community diversity was higher in diseased $C$. lentillifera than in healthy C. lentillifera. Both PCoA results and UPGMA results indicated that the healthy and diseased algae samples have characteristically different microbial communities. The predominant prokaryotic phyla were Proteobacteria, Planctomycetes, Bacteroidetes, Cyanobacteria, Acidobacteria, Acidobacteria and Parcubacteria in all sequences. Chlorophyta was the most abundant eukaryotic phylum followed by Bacillariophyta based on $18 \mathrm{~S}$ rDNA sequencing. Ascomycota was the dominant fungal phylum detected in healthy $C$. lentillifera based on ITS sequencing, whereas fungi was rare in diseased C. lentillifera, suggesting that Ascomycota was probably fungal endosymbiont in healthy C. lentillifera. There was a significantly higher abundance of Bacteroidetes, Cyanobacteria, Bacillariophyta, Ulvales and Tetraselmis in diseased C. lentillifera than in healthy C. lentillifera. Disease outbreaks significantly change carbohydrate metabolism, environmental information processing and genetic information processing of prokaryotic communities in C. lentillifera through predicted functional analyses using the Tax4Fun tool.
\end{abstract}

Conclusions: Bacteroidetes, Cyanobacteria, Bacillariophyta, Ulvales and Tetraselmis outbreak at the C. lentillifera farm sites was an important factor contributing to disease in C. lentillifera.

Keywords: Caulerpa lentillifera, High-throughput sequencing, Microbial community, Diversity, Diseased

\footnotetext{
* Correspondence: liufl@ysfri.ac.cn

'Key Laboratory of Sustainable Development of Marine Fisheries, Ministry of Agriculture and Rural Affairs, Yellow Sea Fisheries Research Institute, Chinese Academy of Fishery Sciences, Qingdao, China

${ }^{2}$ Laboratory for Marine Fisheries Science and Food Production Processes, Qingdao National Laboratory for Marine Science and Technology, Qingdao, China

Full list of author information is available at the end of the article
}

(c) The Author(s). 2019 Open Access This article is distributed under the terms of the Creative Commons Attribution 4.0 International License (http://creativecommons.org/licenses/by/4.0/), which permits unrestricted use, distribution, and reproduction in any medium, provided you give appropriate credit to the original author(s) and the source, provide a link to the Creative Commons license, and indicate if changes were made. The Creative Commons Public Domain Dedication waiver (http://creativecommons.org/publicdomain/zero/1.0/) applies to the data made available in this article, unless otherwise stated. 


\section{Background}

Caulerpa lentillifera, also known as sea grape or green caviar, is a coenocytic green alga having a wide distribution in the tropical Indo-Pacific region $[18,50,58,67] . C$. lentillifera is characterized by a thallus consisting of long horizontal stolons with many erect grapelike branches above and filiform rhizoidal branches below. The erect branches are populated with many small spherical ramuli, each tightly attached to the main axis [49]. C. lentillifera is a popular seafood delicacy in Japan, Korea, Philippines and other southeast Asian countries, eaten fresh or as a salt-preserved form. Its bright green color, delicate flavor, and soft and succulent texture make it highly sought after by consumers. Due to its nutritional and health value, with antibacterial and anti-inflammatory properties [53], it has received more attention in recent years and is rapidly becoming one of the most important economic green macroalgae in the world.

Increasing consumer demand has led to the commercial cultivation of $C$. lentillifera in Japan and Vietnam in recent decades. Cultivation methods vary and are adapted in different ways, depending on the country and site conditions. For instance, C. lentillifera is cultivated using a bottom-planting method in the Philippines [36], an off-bottom tray method in Vietnam, and a land-based raceway method in Japan [66]. The increasing demand for domestic consumption as well as international trade has promoted the commercial cultivation of $C$. lentillifera in China in recent years. Concomitant with the increase of $C$. lentillifera cultivation is a rise in disease associated with this species, particularly, invasion of epiphytes or bacteria.

In 2017, a disease outbreak occurred at a C. lentillifera farm in Dalian city with some obvious biofouling attachment on the surface of $C$. lentillifera. The spherical ramulis of the infected algae turned pink-red and detached from the diseased erect branches once the disease became severe, after which the infected algae decayed gradually. However, the causative agents and associated factors giving rise to the disease outbreak remain unclear.

Interactions among macroalgae and other attaching organisms including epiphyte and endophyte, such as bacteria and fungus, are complex. They can interact with each other, either synergistically or antagonistically. On the one hand, macroalgae harbor a rich diversity of associated microorganisms with functions related to host health and defense, which interact as a unified functional entity or holobiont [25]. Bacterial species and strains having similar metabolic functions were found to colonize similar algal taxa or algal groups [30]. Those bacteria with antifouling properties are thought to protect chemically undefended macroalgae from detrimental, secondary colonization by other microscopic and macroscopic epibiota [25].
On the other hand, the epiphytes and microorganisms may have negative effects to the macroalgae, including competition for nutrients, increasing the attachment and growth of a variety of other biofouling organisms, such as diatoms and other epiphyte algae spores, inhibiting gas exchange as well as reducing the availability of light and subsequent photosynthetic activity [20, 59].

Microorganisms are increasingly being recognized as the causative agents in the diseases of macroalgae [77] and epiphyte outbreaks have shown to weaken the seaweed, making it susceptible to bacterial attack [70]. Recent molecular studies have explored the epiphytic and bacterial diversity on some macroalgal species including Caulerpa $[1,6,39,68]$. However, little is known of the microbial community structure and diversity for $C$. lentillifera.

A better insight into mutualistic interactions between macroalgae and other eukaryotes or prokaryotes is necessary for understanding and predicting algal disease outbreaks [30]. For studying prokaryotes, PCR amplification of the ubiquitous $16 \mathrm{~S}$ ribosomal RNA (rRNA) gene is commonly used. Sequencing the variable regions of this gene allows precise taxonomic identification. For studying eukaryotic microbes such as fungi, as the equivalent rRNA gene (18S) may not provide sufficient taxonomic discrimination, the hypervariable internal transcribed spacer (ITS) is often used [69]. However, the $18 \mathrm{~S}$ rRNA gene is more conserved and provides an independent measure of eukaryotic diversity that can identify biases in ITS analysis [54]. Hence, to determine the identity of the causal organism on the $C$. lentillifera, the prokaryotic and eukaryotic microorganism community structures and diversities of healthy and diseased $C$. lentillifera were explored using $16 \mathrm{~S}$ rDNA, $18 \mathrm{~S}$ rDNA, and ITS high-throughput sequencing in the present study. The use of high-throughput sequencing technologies has been widely adopted as they allow the identification of thousands to millions of sequences in a sample, revealing the abundances of even rare microbial species [69]. To the best of our knowledge, this is the first high-throughput amplicon sequencing study on the microbial community structure and diversity in $C$. lentillifera. The findings from such investigations may shed light on the cause and process of disease outbreaks in $C$. lentillifera and such knowledge would benefit the ability to control for disease under cultivation conditions.

\section{Results}

Richness and diversity

After filtering chimeric sequences and mismatches, the total number of $\mathrm{V} 3-\mathrm{V} 4$ region of the $16 \mathrm{~S}$ rRNA 
gene reads, V4 region of the $18 \mathrm{~S}$ rRNA gene reads, and ITS2 region reads obtained from the 12 samples, was $1,023,109,1,559,260$ and $1,171,931$, respectively. They were respectively clustered into 14,050, 2479 and 941 OTUs at a cut-off of $97 \%$ sequence similarity, respectively. Rarefaction curves of most samples tend to be flat (Fig. 1), suggesting that a reasonable sequencing depth has been attained, although extra rare bacterial taxa are likely present in the sample. This was further supported by high Good's coverage estimates (Table 1).

The average OTU numbers, community richness and community diversity of each group are shown in Table 1. Both the richness indices (including ACE index and Chaol index) and diversity indices (including Shannon index and Simpson index) were higher in $16 \mathrm{~S}$ rDNA groups than in $18 \mathrm{~S}$ rDNA groups or ITS groups. The $16 \mathrm{~S}$ rDNA and $18 \mathrm{~S}$ rDNA OTUs detected in all algae groups (CK, SA, DA) were both more abundant than in the sediment group (AO). The OTUs and richness indices detected in CK were more abundant in the ITS groups. Moreover, all the community richness and diversity indices in all algae groups were higher than in the sediment group, indicating that additional OTUs are likely present in AO, although coverage estimates were very high for all samples. There was no significant difference in the richness indices (including Ace and Chao) between $\mathrm{SA}$ and $\mathrm{DA}$ in the same amplicon sequencing group $(p>0.05)$.

The Shannon index of SA in 16S rDNA groups and both the Shannon and Simpson indices of SA in $18 \mathrm{~S}$ rDNA groups were significantly greater than those of CK $(p<0.05)$. There was a significantly greater Shannon index in SA compared to that of DA in $16 \mathrm{~S}$ rDNA groups $(p<0.05)$. Moreover, both the Shannon and Simpson indices were significantly higher in SA than those of DA in ITS groups $(p<0.05)$. However, the richness index and Shannon index were both found to be significantly higher in CK than those of other groups based on ITS sequencing $(\mathrm{p}<0.05)$.

\section{Prokaryotic community composition}

The composition of prokaryotes at the phylum level was analyzed (Fig. 2a). Twenty-five prokaryotic phyla were detected in all samples, however, only seven of these phyla accounted for more than $96.9 \%$ of all sequences. The predominant phyla were Proteobacteria (52.1\%), Planctomycetes (21.1\%), Bacteroidetes (13.5\%), Cyanobacteria (7.8\%), Acidobacteria (1.0\%), Acidobacteria (1.0\%) and Parcubacteria $(0.5 \%)$ in all sequences. The unclassified prokaryote at phylum level accounted for $1.0 \%$ of all sequences. Proteobacteria was the most predominant phylum, accounting for $65.3,55.7,64.6$, and $22.9 \%$ of the reads in CK, SA, DA, and AO libraries respectively. Planctomycetes was the second most predominant phylum with proportions of $20.8,16.7,12.8$, and $33.9 \%$ in CK, SA, $\mathrm{DA}$, and $\mathrm{AO}$ respectively. The abundance of Bacteroidetes in CK was significantly lower than in SA and DA $(p<0.05)$. The abundance of Cyanobacteria in CK was very low, accounting for only $0.1 \%$ in $\mathrm{CK}$ and was significantly lower than in SA or DA $(\mathrm{p}<0.05)$. Moreover, the abundance of Cyanobacteria in $\mathrm{AO}$ was very high, accounting for $22.7 \%$.

The relative abundance of predominant prokaryotes at the order and genera level are shown in Fig. 2b and $\mathrm{c}$ respectively. The unclassified prokaryote at order and genera level accounted for 17.8 and $43.1 \%$ of all sequences respectively. Rhodobacterales and Leisingera were the most predominant order and genera respectively. Rhodobacterales accounted for 22.0, 24.5, 24.3 , and $7.1 \%$ of the reads, and Leisingera accounted for $0.8,9.5,11.0$, and $0.4 \%$ of the reads in $\mathrm{CK}, \mathrm{SA}$,
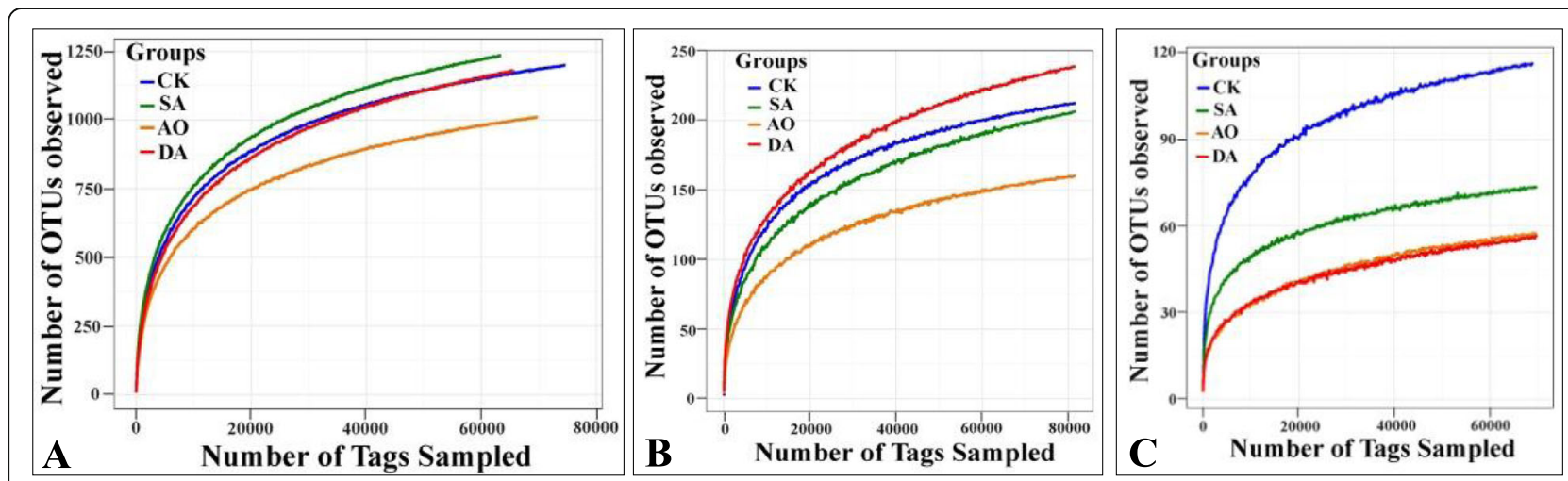

Fig. 1 The rarefaction analysis of all samples. a 16S rDNA; (b) 18S rDNA; (c) ITS. Rarefaction curves of OTUs clustered for a dissimilarity of 3\%. CK, SA, DA represent the healthy, diseased, and decayed algae samples respectively. AO represents the sediment samples collected from the algae farm 
Table 1 Richness and diversity estimation of the 165 rDNA, 18S rDNA, and ITS sequencing libraries

\begin{tabular}{clllllll}
\hline Sample & OTUs & ACE & Chao1 & Shannon & Simpson & Coverage(\%) & Effective Tags \\
\hline 16S rDNA & & & & & & \\
CK & $1217 \pm 254 \mathrm{a}$ & $1394 \pm 219 \mathrm{a}$ & $1405 \pm 212 \mathrm{a}$ & $6.921 \pm 0.072 \mathrm{~b}$ & $0.971 \pm 0.004 \mathrm{a}$ & $99.730 \pm 0.027 \mathrm{a}$ & $84,020 \pm 5587 \mathrm{a}$ \\
SA & $1239 \pm 56 \mathrm{a}$ & $1437 \pm 89 \mathrm{a}$ & $1465 \pm 92 \mathrm{a}$ & $7.570 \pm 0.402 \mathrm{a}$ & $0.982 \pm 0.010 \mathrm{a}$ & $99.614 \pm 0.048 \mathrm{~b}$ & $87,206 \pm 2441 \mathrm{a}$ \\
DA & $1206 \pm 198 \mathrm{a}$ & $1422 \pm 198 \mathrm{a}$ & $1438 \pm 196 \mathrm{a}$ & $6.909 \pm 0.406 \mathrm{~b}$ & $0.971 \pm 0.011 \mathrm{a}$ & $99.645 \pm 0.019 \mathrm{~b}$ & $82,879 \pm 8562 \mathrm{a}$ \\
AO & $1022 \pm 72 \mathrm{a}$ & $1178 \pm 79 \mathrm{a}$ & $1185 \pm 76 \mathrm{a}$ & $6.614 \pm 0.117 \mathrm{~b}$ & $0.959 \pm 0.002 \mathrm{~b}$ & $99.734 \pm 0.004 \mathrm{a}$ & $86,932 \pm 5643 \mathrm{a}$ \\
18S rDNA & & & & & & \\
CK & $214 \pm 25 \mathrm{a}$ & $252 \pm 43 \mathrm{~b}$ & $244 \pm 30 \mathrm{a}$ & $1.288 \pm 0.258 \mathrm{c}$ & $0.264 \pm 0.062 \mathrm{c}$ & $99.953 \pm 0.009 \mathrm{ab}$ & $11,664 \pm 3851 \mathrm{c}$ \\
SA & $209 \pm 26 \mathrm{a}$ & $262 \pm 13 \mathrm{ab}$ & $262 \pm 20 \mathrm{a}$ & $2.729 \pm 0.107 \mathrm{a}$ & $0.706 \pm 0.073 \mathrm{a}$ & $99.940 \pm 0.002 \mathrm{bc}$ & $11,934 \pm 1426 \mathrm{c}$ \\
DA & $240 \pm 7 \mathrm{a}$ & $291 \pm 7 \mathrm{a}$ & $292 \pm 4 \mathrm{a}$ & $3.182 \pm 0.497 \mathrm{a}$ & $0.763 \pm 0.053 \mathrm{a}$ & $99.934 \pm 0.005 \mathrm{c}$ & $14,693 \pm 8656 \mathrm{a}$ \\
AO & $163 \pm 5 \mathrm{~b}$ & $195 \pm 22 \mathrm{c}$ & $195 \pm 14 \mathrm{~b}$ & $1.922 \pm 0.066 \mathrm{~b}$ & $0.478 \pm 0.017 \mathrm{~b}$ & $99.961 \pm 0.009 \mathrm{a}$ & $13,682 \pm 2948 \mathrm{~b}$ \\
ITS & & & & & & \\
CK & $118 \pm 10 \mathrm{a}$ & $129 \pm 1 \mathrm{a}$ & $133 \pm 11 \mathrm{a}$ & $3.006 \pm 0.110 \mathrm{a}$ & $0.785 \pm 0.026 \mathrm{a}$ & $99.977 \pm 0.002 \mathrm{a}$ & $77,855 \pm 1035 \mathrm{C}$ \\
SA & $76 \pm 5 \mathrm{~b}$ & $88 \pm 9 \mathrm{~b}$ & $89 \pm 8 \mathrm{~b}$ & $2.423 \pm 0.148 \mathrm{~b}$ & $0.713 \pm 0.028 \mathrm{a}$ & $99.984 \pm 0.003 \mathrm{a}$ & $10,744 \pm 2269 \mathrm{ab}$ \\
DA & $59 \pm 6 \mathrm{c}$ & $78 \pm 25 \mathrm{~b}$ & $78 \pm 1 \mathrm{~b}$ & $1.219 \pm 0.615 \mathrm{C}$ & $0.354 \pm 0.211 \mathrm{~b}$ & $99.983 \pm 0.006 \mathrm{a}$ & $94,962 \pm 9216 \mathrm{~b}$ \\
AO & $60 \pm 5 \mathrm{c}$ & $69 \pm 8 \mathrm{~b}$ & $70 \pm 9 \mathrm{~b}$ & $1.692 \pm 0.181 \mathrm{c}$ & $0.495 \pm 0.040 \mathrm{~b}$ & $99.986 \pm 0.005 \mathrm{a}$ & $11,038 \pm 6244 \mathrm{a}$ \\
\hline
\end{tabular}

The cutoff value was 0.03 (sequence identity 0.97 ). ACE and Chao1 indices were used to evaluate the community richness, while Shannon and Simpson indices were used to assess the community diversity. The values of mean \pm SD of three samples are shown in the table. The different letters superscript indicate significant differences. CK, SA, DA represent the healthy, diseased, and decayed algae samples respectively. AO represents the sediment samples collected from the algae farm

DA, and AO libraries respectively. The abundance of Planctomycetales, Oceanospirillales, Aestuariibacter, Neptuniibacter, Labrenzia, Bythopirellula, and Blastopirellula in CK were all significantly higher compared to those in SA or DA $(p<0.05)$. Conversely, the abundance of Flavobacteriales, Phycisphaerales, Cellvibrionales, Rhodospirillales, Leisingera, and SM1A02 in
CK were all significantly lower compared to those in SA or DA $(\mathrm{p}<0.05)$.

\section{Eukaryotic community composition based on $18 \mathrm{~S}$ rDNA sequencing}

Figure 3 shows the composition of eukaryotes at the phylum, order and genera level based on 18S rDNA

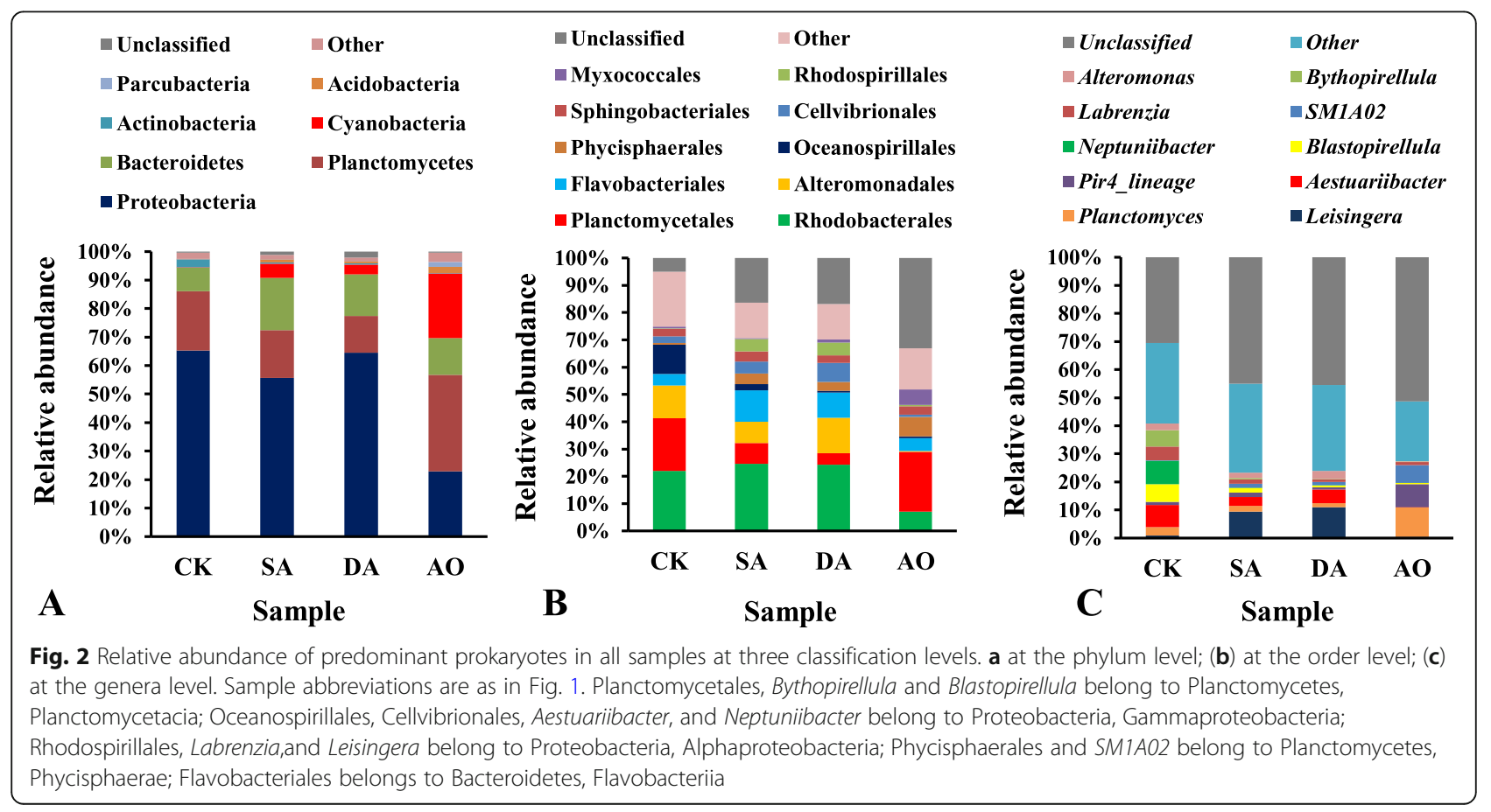




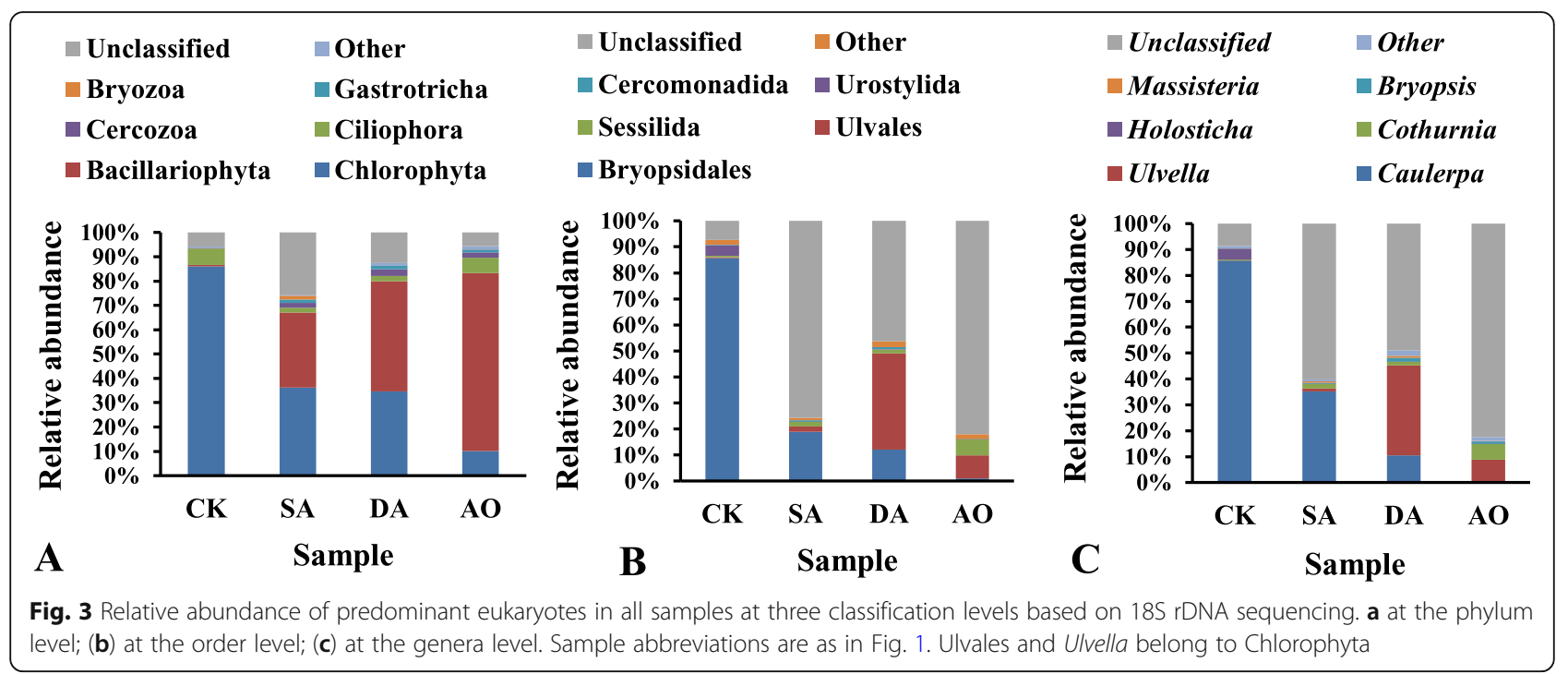

sequencing. Sixteen eukaryotic phyla were detected in all samples based on $18 \mathrm{~S}$ rDNA sequencing, however, only six of these accounted for about $86.7 \%$ of all sequences. The predominant phyla were Chlorophyta, Bacillariophyta, Ciliophora, Cercozoa, Gastrotricha and Bryozoa, among which Plantage and Animalia accounted for about 79.2 and $7.5 \%$ of all sequences respectively. Within the fungal domain, Ascomycota and Basidiomycota were detected, but the abundance of both was negligible in the samples. The unclassified eukaryote at phylum and genera level accounted for 12.4 and $50.1 \%$ of all sequences respectively based on $18 \mathrm{~S}$ rDNA sequencing. Chlorophyta was the most predominant phylum, making up $86.0,36.2,34.6$, and $10.1 \%$ of the reads in CK, SA, $\mathrm{DA}$, and AO libraries respectively. Bacillariophyta was the second most predominant phylum, which accounted for $0.6,30.8,45.4$, and $73.1 \%$ in CK, SA, DA, and AO respectively. The abundance of Bacillariophyta in CK was significantly lower than in other groups $(p<0.05)$, while the abundance of Ciliophora, Urostylida and Holosticha (belonging to Protozoa) in CK were all significantly higher than in SA and DA $(\mathrm{p}<0.05)$. Ulvales were the dominant order, which accounted for $37.0 \%$ in DA, while only making up 0.3 and $2.0 \%$ of the reads in CK and SA respectively. Moreover, at the genera level, Ulvella accounted for $34.7 \%$ in DA but only accounted for 0.1 and $1.1 \%$ in CK and SA respectively. Thus implying that Ulvales or Ulvella grew abundantly on C. lentillifera when $C$. lentillifera decayed.

\section{Eukaryotic community composition based on ITS sequencing}

The relative abundance of predominant eukaryotes at the phylum, order and genera level based on ITS

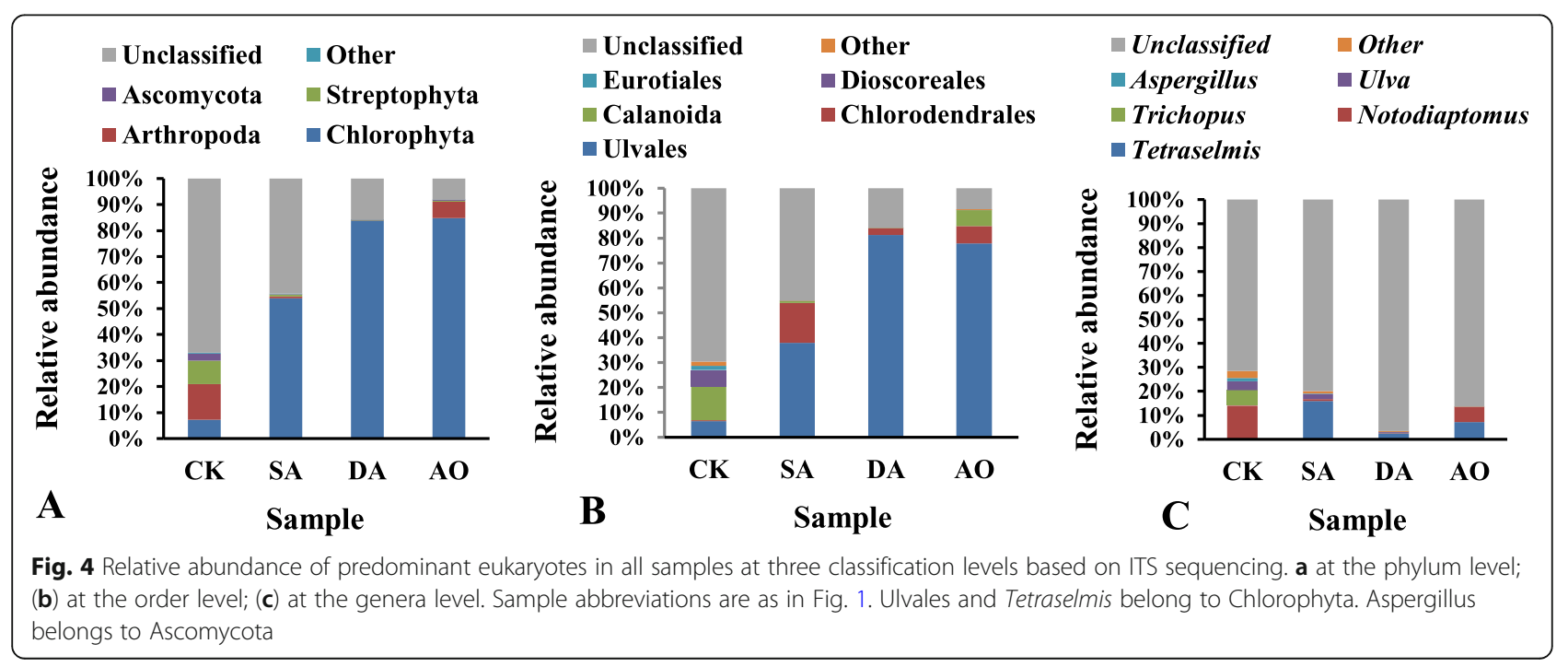


sequencing were shown at Fig. 4. Only five eukaryotic phyla were detected in all samples and the unclassified eukaryote at phylum, order and genera level accounted for $33.9,34.8$ and $83.6 \%$ of all sequences respectively. Unlike the result of $18 \mathrm{~S}$ rDNA sequencing for the fungal domain, Ascomycota was one of the dominant phyla based on ITS sequencing, the abundance $(2.7 \%)$ of which was significantly higher in CK than in the other groups $(p<0.05)$. Moreover, Aspergillus, a genus of fungi in the order Eurotiales (phylum Ascomycota), was also significantly higher in CK than in the other groups $(p<0.05)$, but Aspergillus could not be detected in AO based on ITS sequencing. In similarity with the result of $18 \mathrm{~S}$ rDNA sequencing at the order level, Ulvales were the dominant order. The abundance of Ulvales in CK was significantly lower than in the other groups $(p<0.05)$, while the abundance of Arthropoda, Calanoida and Notodiaptomus (belonging to Metazoa) in CK were all significantly higher than in SA and DA $(\mathrm{p}<0.05)$. At the genera level, Tetraselmis, a genus of green microalga, accounted for $16.1 \%$ in SA but only accounted for 0.2 and $2.6 \%$ in CK and DA respectively.

\section{Relationships among the microbial communities in the different samples}

Ordination by principal coordinates analysis (PCoA) of prokaryotes (Fig. 5a) and eukaryotes (Fig. 5b, c) communities was performed to reveal the relationships among the different samples. Based on $16 \mathrm{~S}$ rDNA sequencing, $18 \mathrm{~S}$ rDNA sequencing and ITS sequencing, the first principal coordinates axis (PCo1) alone explained 30.37, 35.13 and $30.55 \%$ of variance, respectively, and the second principal coordinates axis (PCo2) alone explained $23.72,20.79$ and $15.75 \%$ of variance, respectively. The CK samples were grouped on the left-hand side of the graph along PCo1. Figure 6 shows the relationships among the microbial communities in the different samples at the phylum level based on UPGMA method. Both PCoA and UPGMA analysis results showed that the SA and DA samples tended to cluster together based on $16 \mathrm{~S}$ rDNA sequencing, suggesting that the diseased and decayed algae samples have similar characteristic prokaryotic microorganism communities. And both SA and DA samples were distinct from $\mathrm{CK}$ or AO samples based on $16 \mathrm{~S}$ rDNA sequencing or $18 \mathrm{~S}$ rDNA sequencing. However, the DA and AO samples tended to cluster together based on ITS sequencing. It implied that the relatedness of eukaryotic community between diseased and decayed algae samples was not in agreement based on different sequencing methods.

\section{Predicted functional analysis for microbial communities throughTax4Fun and FUNGuild}

The predicted functional analyses for prokaryotic communities of all samples were carried out using the Tax4Fun tool. Heat map of the 20 KEGG level-2 functional pathways with relatively high abundance are shown in Fig. 7. The predicted functional analysis in all samples found affiliations with metabolic pathways of carbohydrate, energy, nucleotide, amino acids, cofactors and vitamins, and environmental information processing pathways of signal transduction, membrane transport, and genetic information processing pathways of translation, folding, sorting and degradation, and cellular processes pathways of cell motility, cell growth and death. Out of total KEGG subsystems found, carbohydrate metabolism was the highest in abundance in CK, whereas the abundances of nucleotide and amino acids metabolism were found to be significantly lower in CK than in other groups $(p<$ 0.05). Moreover, pathways of membrane transport, signal transduction and translation were significantly different in CK compared with those in other groups $(\mathrm{p}<0.05)$.

The predicted functional analyses for fungal communities in all treatments were carried out using the FUNGuild tool. The relative abundance of 14 fungal functional guilds (not including unassigned taxa) such as

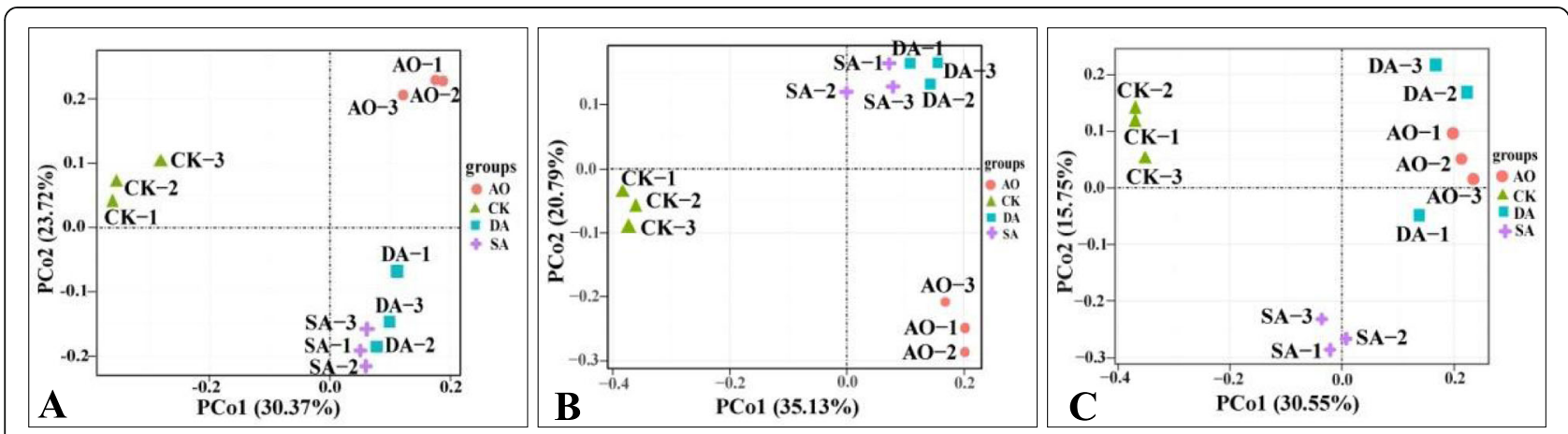

Fig. 5 Principal Coordinates Analysis (PCOA) results showing the relatedness of microbial communities in the different samples. The PCoA plots were constructed with the unweighted UniFrac PCoA method. a $16 \mathrm{~S} \mathrm{rDNA;} \mathrm{(b)} \mathrm{18S} \mathrm{rDNA;} \mathrm{(c)} \mathrm{ITS.} \mathrm{Sample} \mathrm{abbreviations} \mathrm{are} \mathrm{as} \mathrm{in} \mathrm{Fig.} 1$ 

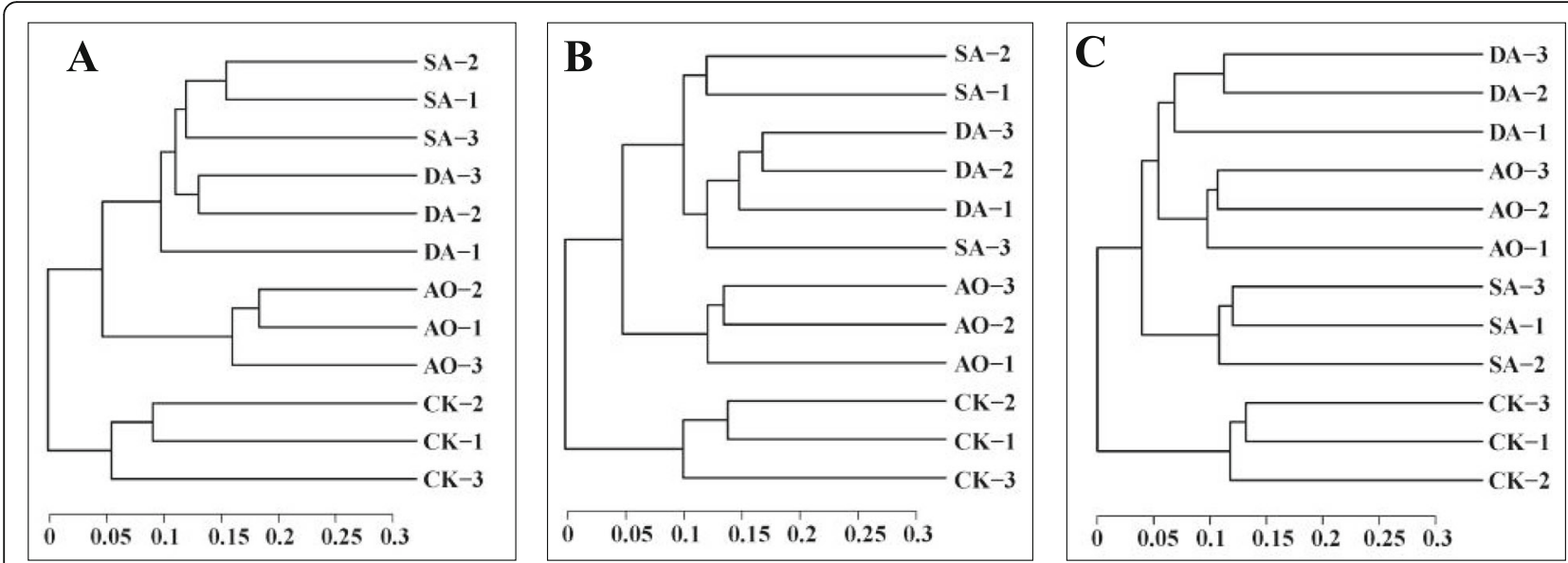

Fig. 6 UPGMA clustering analysis based on unweighted unifrac distance matrix at the phylum level. a 16S rDNA; (b) 18S rDNA; (c) ITS. Sample abbreviations are as in Fig. 1

plant pathogen, fungal parasite and undefined saprotroph were detected (Fig. 8). The unclassified reads made up a very high proportion (over 97\%), reflecting the limitations in the FUNGuild database. The "undefined saprotroph" was the maximum abundance guild followed by "endophyte-plant pathogen-animal pathogen-wood saprotroph" guild, "endophyte-plant pathogen" guild. The above three guilds with relative high abundance accounted for 1.9, 0.7, 0.1\% of all sequences respectively in $\mathrm{CK}$, but decreased significantly $(p<0.05)$ in other samples.

\section{Discussion}

\section{Microbial richness and diversity}

Macroalgal surfaces harbor a rich community composed of bacteria, fungi, diatoms, protozoa, spores and larvae of marine invertebrates [40] that can benefit from the availability of various organic substances produced by algae [3]. Bacteria are dominant among primary colonizers [39], whereas fungi appear to be rare in the marine environment [43]. Using high-throughput sequencing, we found that both the richness and diversity of prokaryotic communities were significantly higher

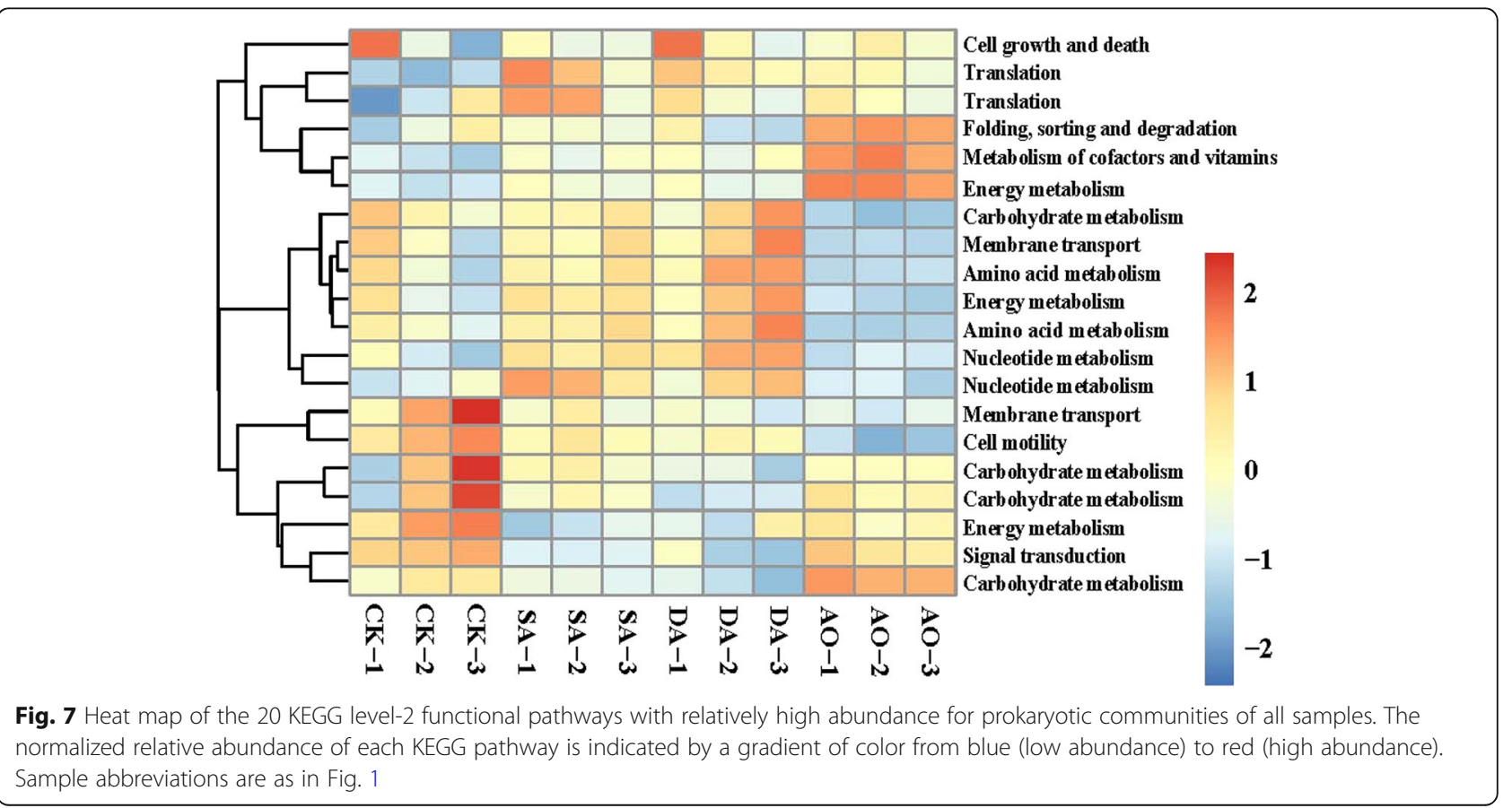




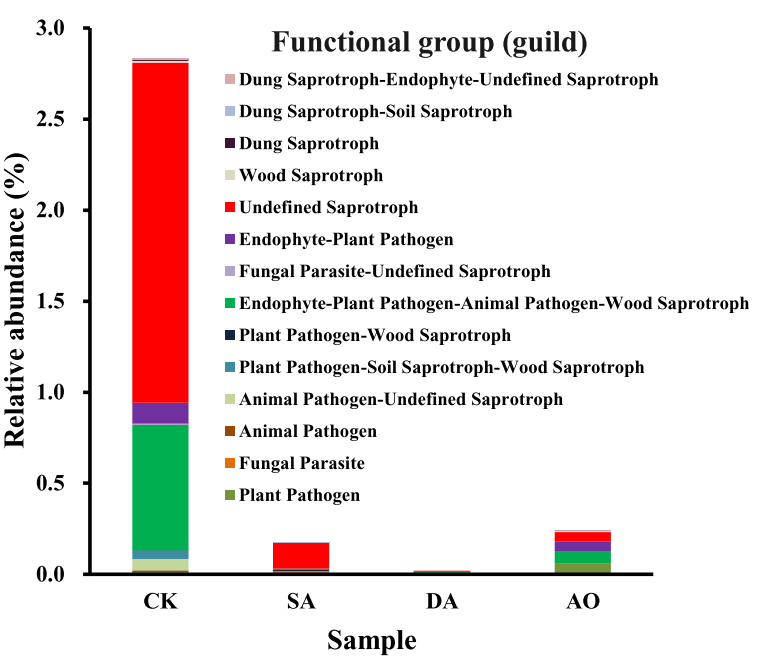

Fig. 8 Relative abundance of predicted fungal functions. Unassigned taxa (>97\%) are not shown. Samples abbreviations are as in Fig. 1

than those of eukaryotic communities in all experimental groups in the present study. This implies that prokaryotic organisms are dominant among primary colonizers in the $C$. lentillifera farm. We also found that the microbial richness and diversity among all algae samples were both significantly higher than in the sediment samples, indicating that the microorganisms tended to cluster together around the algae rather than at the bottom of the tank of the C. lentillifera farm. Other studies have shown that marine macroalgae are generally associated with specific bacterial communities which differ significantly from those occurring in the surrounding seawater $[39,46]$. Both PCoA results and UPGMA results in the present study indicated that among the healthy algal samples, diseased algal samples, and sediment samples, there were different characteristic microbial communities.

Many studies have proposed that there is a mutualistic relationship in which the bacterial community protects the host algae against secondary biological fouling, while the host surface provides nutrients and physical protection to the associated bacteria [57]. Bacteria in a biofilm can affect the growth of other bacteria in the same biofilm [14]. For example, the presence of "resident" bacterial strains on particles either increases or decreases the colonization rate of "newcomer" strains [33]. The accumulative effects of mutualism can facilitate conspecific recruitment and increase the dominance of abundant species, reducing diversity [8]. Generally, 16S rDNA sequencing and $18 \mathrm{~S}$ rDNA sequencing showed that microbial community diversity was higher in the diseased C. lentillifera than in the healthy $C$. lentillifera. Thus, it can be inferred that accumulation of some mutualistic microorganisms may play an important role for the health of $C$. lentillifera. The microbial community diversity was found to be lower in the diseased C. lentillifera than in decayed $C$. lentillifera by $16 \mathrm{~S}$ rDNA sequencing and ITS sequencing, suggesting that a decrease of microbial community diversity may be one of the reasons leading to algal decay. However, the interaction between microbiota and their host is more complex than just a high or low microbial diversity. Thus, no general statements can be made on the role of microbial diversity in health and disease, since different microbe-host interactions are involved in the pathophysiology of different diseases.

\section{Prokaryotic community composition}

Lachnit et al. [40] found that epibacterial community patterns on macroalgae were generally highly host specific but temporally variable. A study by Goecke et al. [30] who isolated bacterial species from more than 42 algal species from marine and freshwater environments found that the two major bacterial groups associated with algae were Bacteroidetes and Proteobacteria, followed by Firmicutes, Actinobacteria, Verrucomicrobia, and Planctomycetes. Yet another study found that bacterial communities belonging to the phyla Proteobacteria and Firmicutes were generally the most abundant on seaweed surfaces [63].

Some bacterial species are considered as an essential functional component of the algal holobiont [61]. Certain physiological properties of bacterial species (i.e. polysaccharide degradation, antibiotic production, growth stimulant production, biosynthesis of allelochemicals, etc.) may favour the establishment of ecological relationships between epibionts and the alga $[15,16]$. 


\section{Community composition of prokaryote belonging to the phylum Proteobacteria}

Through $16 \mathrm{~S}$ rDNA sequencing we found that the abundance of Oceanospirillales, Neptuniibacter (belonging to Oceanospirillales) and Aestuaribacter (belonging to Alteromonadales), belonging to phylum Proteobacteria, were all significantly higher in healthy $C$. lentillifera than in diseased and decayed C. lentillifera. Numerous studies have demonstrated the contribution of bacteria to nutrient acquisition or defense by the production of vitamins [74]. Bertrand et al. [9] identified Oceanospirillaceae ASP10-02a as a possible vitamin $B_{12}$ producer in sea-ice edge microbial communities, providing evidence of symbioses between algae and bacteria for vitamin $B_{12}$ acquisition in the natural environment. Thus, it can be inferred that Oceanospirillales and Neptuniibacter may contribute to the health of C. lentillifera by stimulanting their growth. The most frequently reported bioactive bacterial metabolites have been isolated from species of the genera Alteromonas, Bacillus and Pseudoalteromonas. El Bour et al. [26] isolated Alteromonas marina and Alteromonas macleodii from Ulva rigida and verified that Alteromonas showed antibacterial and antifungal bioactivity. Aestuaribacter shares many traits with the sister genus Alteromonas. Therefore, we proposed that Aestuariibacter may favour the health of C. lentillifera via antibiotic production.

\section{Community composition at the alphaproteobacterial Roseobacter group (Rhodobacteraceae, Proteobacteria)}

The abundance of genus Leisingera, which belongs to the family Rhodobacteraceae, order Rhodobacterales of the class Alphaproteobacteria, and the abundance of order Rhodospirillales were both significantly lower in healthy C. lentillifera than in diseased and decayed C. lentillifera. However, the abundance of genus Labrenzia, which is the sister genus with Leisingera, was higher in healthy C. lentillifera than in other samples. The alphaproteobacterial Roseobacter group (Rhodobacteraceae) plays a global role in marine ecosystems with an important role for carbon and sulfur cycling, whose abundance can reach $36 \%$ in nutrient-rich costal habitats [52]. It is dominant in the bacterial communities associated with phytoplankton, macroalgae, and various marine animals and both mutualistic and pathogenic life-styles have been suggested [47]. The endophytic bacteria have been microscopically observed in the vacuolar as well as cytoplasmatic regions of various bryopsidalean green algae, including Bryopsis, Halimeda, and Caulerpa. These seaweeds are composed of a single, giant tubular cell and form an interesting biotic environment for bacterial communities [35]. In Caulerpa spp., most of the alpha proteobacterial clones were assigned to the Rhodobacteraceae [51]. A number of Rhodobacteraceae organisms are known to produce unique antimicrobial molecules and other secondary metabolites, presenting a potential for detoxication. For example, the genus Leisingera can produce the antibacterial compound indigoidine [19, 32]. Moreover, it was revealed that the endosymbiotic Alphaproteobacteria in Caulerpa species presented a potential for photosynthesis [22]. For instance, the genus Labrenzia, belonging to one kind of aerobic anoxygenic phototrophic bacteria, was able to produce bacteriochlorophyll in small amounts [10]. Therefore, we inferred that there is a symbiotic relationship between $C$. lentillifera and Leisingera/Labrenzia. On the one hand, Leisingera and Labrenzia may contribute to the photosynthesis of algae and be favourable for C. lentillifera via antibiotic production. On the other hand, significantly increasing Leisingera in the bacterial community may not favour the health of the host. Algal diseases usually result from the interaction of environmental factors, pathogen and algae stress response. In certain circumstances, some bacteria produce metabolites and degrade the cell wall of algae. Hence, further investigations for the role of Leisingera and Labrenzia in the microbial community of C. lentillifera should be undertaken.

Biebl et al. (2007) found that Labrenzia colonies are white to cream, but may become pink if incubated in the dark under appropriate conditions, and Riedel et al. [60] found that Leisingera colonies are dark beige-pink in color. It follows that giving consideration to the color of Rhodobacteraceae colonies and their potential for detoxication, increase in the abundance of Rhodobacteraceae (especially the genus Leisingera) may be one of the reasons leading to $C$. lentillifera frond turning pink-red with disease outbreaks. Furthermore, it was frequently observed that the parental frond of $C$. lentillifera would also turn pink-red when they were placed at the bottom of trays under long-term low light conditions. The parental algae' color changing may be related to Rhodobacteraceae.

\section{Community composition of prokaryote belonging to the phylum Planctomycetacia}

Using 16S rDNA sequencing, the abundance of Planctomycetales, Bythopirellula (Planctomycetes) and Blastopirellula (Planctomycetes), were significantly higher in healthy $C$. lentillifera than in diseased and decayed samples of $C$. lentillifera, indicating that Planctomycetes were likely to play a crucial role in the biofilm community of $C$. lentillifera. Through analysis of long chain proteins in the genomes of three Planctomycetes, Faria et al. [28] proposed that Planctomycetes may play an important role in biofilm formation and against stress agents in the complex biofilm of macroalgae. Bengtsson \& Øvreås [7] established the importance of Planctomycetes in the biofilm community of the kelp Laminaria hyperborea, accounting for 51-53\% of the total bacteria. Moreover, several studies also have shown that Planctomycetes appeared frequently in the epibacterial 
community of macroalgae, presenting clear evidence of an intimate nutritional relationship between Planctomycetes and macroalgae [12, 15, 16, 40, 42, 46]. It has been suggested that the high number of sulfatases found in Planctomycetes could play a major role in the degradation of sulfated polysaccharides in their environment [72]. We therefore speculated that Planctomycetes may also be involved in the utilization of the sulphated polymers produced by the $C$. lentillifera.

\section{Community composition of prokaryote belonging to the phyla Bacteroidetes and cyanobacteria}

Members of the phylum Bacteroidetes are the most abundant group of bacteria in the ocean after Proteobacteria and Cyanobacteria [29]. It was observed that members of Actinobacteria and Bacteroidetes were the most abundant bacterial species on the surface of Caulerpa racemosa [2]. We found that the abundance of Cyanobacteria, Bacteroidetes, and Flavobacteriales (belonging to phylum Bacteroidetes) in diseased and decayed C. lentillifera were all significantly higher than in healthy $C$. lentillifera. Moreover, the abundance of Cyanobacteria in the sediment samples was very high, suggesting that the Cyanobacteria outbreak that occurred at the C. lentillifera farm may be an important factor causing the disease of C. lentillifera. High levels of nitrogen and phosphorus were used in the C. lentillifera farm to assist the algae to grow faster. The eutrophic seawater likely provided a suitable environment for the Cyanobacteria outbreak in the farm.

Bacteroidetes also have a close relationship with Cyanobacteria [62, 75]. Bacterial groups such as Cytophagales/Sphingobacteriales (Bacteroidetes), were previously reported to be associated with some harmful algal species [38]. Sphingobacteriales (one of predominant orders in the prokaryotic community of $C$. lentillifera) are known for their ability to degrade toxins and other cyanobacterial secondary metabolites [45]. Moreover, certain members of Sphingobacteriales such as Saprospiraceae, are known to prey on Cyanobacteria [44]. Therefore, some bacterial groups may increase with Cyanobacteria outbreak. There are some bacterial groups which may produce exopolysaccharide substances and extracellular enzymes capable of degrading macromolecules such as cellulose [51]. This likely lead to the spherical ramulis of the infected algae cleaving from the diseased erect branches of $C$. lentillifera.

However, it remains unknown whether the bacteria associated with $C$. lentillifera are beneficial, so their role needs to be clarified. Further investigations will be needed to understand the potential effect of this prokaryotic assemblage on the patterns of $C$. lentillifera colonization.

\section{Eukaryotic community composition Fungal community composition}

Studies based on culturing and molecular methods have shown that Ascomycetes and anamorphic fungi are the predominant endosymbionts of seaweed [34, 78, 79]. The genus Aspergillus (belonging to phylum Ascomycota) are adapted to survive as endophytes in marine algae and are prolific producers of novel metabolites having possibly coevolved with the algae [21, 65]. The Aspergillus species are common fungal symbionts of many seaweeds including C. racemosa, C. scalpelliformis, C. sertularioides, Ulva lactuca and so on [64]. Moreover, Aspergillusterreus isolated as an endophyte from C. scalpelliformis and C. sertularioides can produce insecticidal compounds [65]. We also found that Ascomycota was the dominant fungal phylum detected in $C$. lentillifera. However, the abundance of Ascomycota and Aspergillus in diseased C. lentillifera was significantly lower than in healthy specimens. Therefore, we hypothesized that Ascomycetes were probably endosymbionts in healthy $C$. lentillifera but the fungal endosymbionts may have difficulty surviving in diseased C. lentillifera. Thus, it would be worthwhile determining the role of Ascomycota in stress tolerance and survival of C. lentillifera, since endophytes elaborate metabolites or strong antioxidants, making their hosts more resistant to biotic stress such as infection by pathogens $[4,73]$ or damage by herbivores [71].

\section{Epiphytic community composition}

The microbial biofilm has been viewed as going through a four-step process: i) adsorption of dissolved organic molecules to a newly submerged surface, ii) colonization of the surface by bacteria, iii) colonization by microscopic eukaryotes (e.g. diatoms, fungi, and other heterotrophic eukaryotes) and iv) settlement and subsequent growth of invertebrate larvae and algal spores [23]. Hence, the establishment of microbial biofilms is regarded as a general prerequisite for the colonization of macroorganisms such as invertebrate larvae and algal spores $[13,56]$. However, biofilms also can inhibit larval settlement of marine invertebrates [37]. We found that the abundance of Protozoa and Metazoa on healthy $C$. lentillifera were both significantly higher than those on diseased $C$. lentillifera, suggesting that biofouling with high abundance of Cyanobacteria on diseased C. lentillifera was possibly secreting antigrazing compounds into the surrounding seawater to prevent the attachment of grazers.

The external morphology of $C$. lentillifera offers a large three-dimensional substratum on which micro algal propagules my settle. Eutrophic seawater may harbour a number of microalgae and macro algal spores, which can lodge and establish themselves on the surface of $C$. lentillifera and are difficult to dislodge from the 
host. Eutrophic seawater is likely to provide an ideal environment for an algal propagules outbreak on the farm. We found that the biofouling by Bacillariophyta, Ulvales and Tetraselmis on the diseased C. lentillifera were much more prolific than those found on the healthy specimens. These biofoulings posed a permanent threat to $C$. lentillifera as they i) increase the hydrodynamic drag on C. lentillifera, thereby enhancing the attachment of other fouling organisms, ii) compete for nutrients, iii) inhibit gaseous exchange, and iv) obscure the macroalgae from ambient light.

This study has given insight into how an outbreak of certain epiphytes such as Bacillariophyta, Ulvales and Tetraselmis, may be another important factor causing disease in C. lentillifera. This conclusion needs more investigation in the future.

\section{Predicted functional analysis for microbial communities}

It was reported that the bacterial community composition on macroalgae is driven by functional genes rather than taxonomic or phylogenetic composition $[15,16]$. Moreover, it is also known that the physiological and biochemical properties of the algal host predetermine the composition of the epiphytic bacterial communities. For example, algal cell wall components and secondary metabolites can trigger specific interactions between macroalgae and beneficial bacteria [27, 41]. In the present study, the results of predicted functional analysis for prokaryotic communities implied that algal disease outbreaks significantly changed carbohydrate metabolism, environmental information processing and genetic information processing among prokaryotic communities. FUNGuild analysis showed that there were significantly different fungal functional groupings (or guilds) between healthy and diseased C. lentillifera groups. Therefore, we conclude that substantial changes in the physiological and biochemical properties of C. lentillifera ensued following the outbreak of algal disease on the farm.

\section{Conclusions}

The prokaryotic and eukaryotic microorganism community structures and diversities in healthy $C$. lentillifera were different from those in diseased $C$. lentillifera. The accumulation of some mutualistic microorganisms may play an important role in the health of $C$. lentillifera. For instance, Oceanospirillales, Neptuniibacter and Aestuariibacter may act as a growth stimulant and in antibiotic production in $C$. lentillifera. There may be a symbiotic relationship between C. lentillifera and Leisingera and Labrenzia. Ascomycetes were probably endosymbionts in the healthy $C$. lentillifera, whereas the fungal endosymbionts have difficulty surviving in diseased C. lentillifera. Epiphytes such as Cyanobacteria, Bacillariophyta, Ulvales and Tetraselmis that occurred at the C. lentillifera farm sites was an important factor contributing to disease in $C$. lentillifera. These results will provide a theoretical basis for controlling $C$. lentillifera diseases.

\section{Methods \\ Experiment procedure \\ Sample collection}

Triplicate samples of healthy, diseased, and decayed individuals of $C$. lentillifera were collected from a C. lentillifera farm in Changhai county, Dalian city, China, in July 2017. The healthy samples of $C$. lentillifera were analyzed as a control, possessing a bright green color without obvious attachment of other macroscopic fouling organisms (Fig. 9a). The diseased samples were those with obvious biofouling attachments and with some spherical ramulis turning pink-red as well as some missing ramuli from the erect branches (Fig. 9b). The decayed samples are shown in the Fig. 9c.
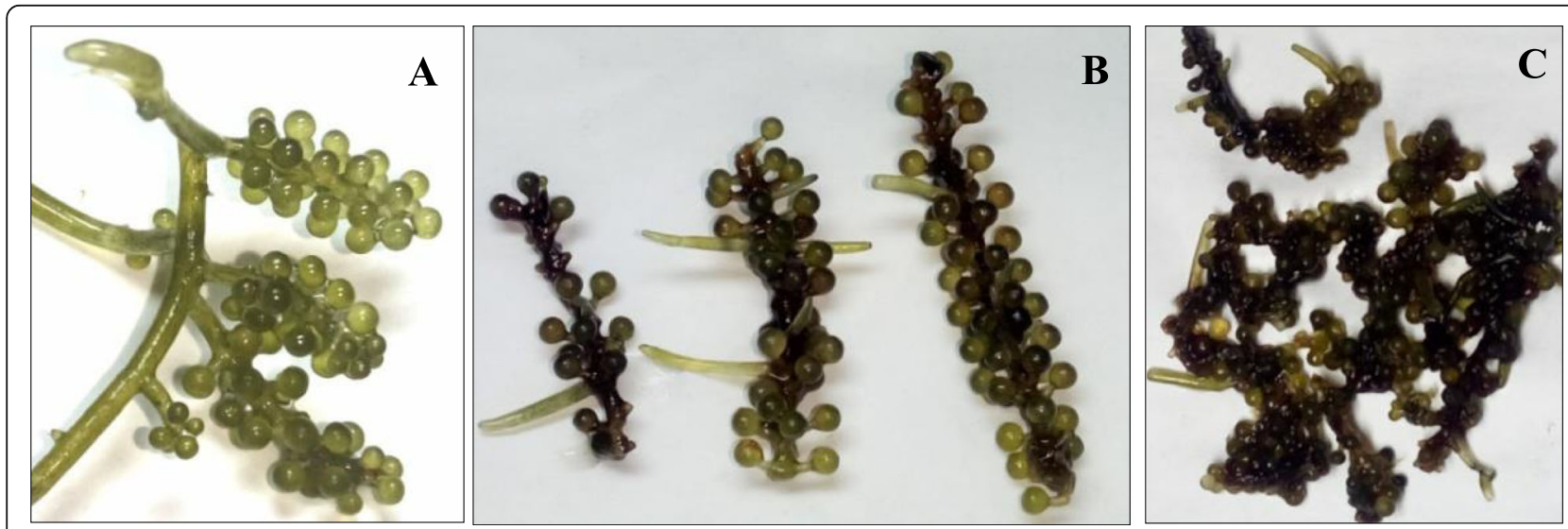

Fig. 9 Healthy (a), diseased (b) and decayed (c) samples at the C. lentillifera farm in Dalian city in China. CK, SA, DA represent the healthy, diseased, and decayed algae samples respectively 
In addition, triplicate samples of sediment were taken from the bottom of the tank in the C. lentillifera farm and were examined for their microbial community structure. Each sample was kept individually enclosed in sterile and sealable plastic bags in situ and transported to the laboratory in a cooler $(<$ $10^{\circ} \mathrm{C}$ ). Within $4 \mathrm{~h}$ after collection, each algal sample was rinsed three times in sterile petri dishes with filtered $(0.22 \mu \mathrm{m}$ pore size $)$ and autoclaved seawater to remove any loosely attached fouling organisms. Subsequently, each sample was gently patted with sterile paper tissue to remove excess seawater and then stored at $-80^{\circ} \mathrm{C}$ before nucleic acid analyses. CK, SA, DA respectively represent the healthy, diseased, and decayed algae samples respectively. AO represents the sediment samples collected from the algae farm.

\section{DNA extraction and polymerase chain reaction (PCR)}

Microbial DNA was extracted from the sample using the E.Z.N.A. DNA Kit (Omega Biotek, Norcross, GA, U.S.) according to the manufacturer's protocols. The extracted total DNA, dissolved in $30 \mu \mathrm{l}$ sterile deionized water, was checked by gel-electrophoresis in 1\% agarose gel, and its purity was examined by NanoDrop spectrophotometer (NanoDrop Technologies, USA). The variable region V3-V4 of the $16 \mathrm{~S}$ rDNA and the variable region $\mathrm{V} 4$ of the $18 \mathrm{~S}$ rDNA were selected for the construction of the prokaryotic and eukaryotic community library for Illumina sequencing, respectively. The specific primer set, 341F: 5'-CCTACGGGNGGC WGCAG-3' and 806R: 5'-GGACTACHVGGGTATCTAAT-3', was used for amplification of the V3-V4 region of $16 \mathrm{~S}$ rDNA. And the specific primer set, 515F: 5'-GTGCCA GCMGCCGCGGTAA-3' and 806R: 5'-GGACTACH VGGGTATCTAAT-3', was used for amplification of the V4 region of $18 \mathrm{~S}$ rDNA. The ITS2 region of the ITS rDNA was also selected for the construction of the eukaryotic community library. The specific primer pair ITS3_KYO2F: 5'GATGAAGAACGYAGYRAA-3' and ITS4R: 5'-TCCTCC GCTTATTGATATGC-3' was used for amplification of the ITS2 region. The barcodes in the primers were an eightbase sequence unique to each sample. All amplifications were performed in $50 \mu \mathrm{l}$ reactions, including $5 \mu \mathrm{l}$ of template DNA $(20 \mathrm{ng} / \mu \mathrm{l}), 1.5 \mu \mathrm{l}$ of each primer $(5 \mu \mathrm{M}), 5 \mu \mathrm{l}$ of each dNTP $(2.5 \mu \mathrm{M}), 5 \mu \mathrm{L}$ of $10 \times$ KOD buffer, and $1 \mu \mathrm{L}$ of KOD Polymerase. The protocol of amplification was as follows: an initial denaturation at $95^{\circ} \mathrm{C}$ for $2 \mathrm{~min}$, followed by 27 cycles of denaturation at $98^{\circ} \mathrm{C}$ for $10 \mathrm{~s}$, annealing at $62^{\circ} \mathrm{C}$ for $30 \mathrm{~s}$, and elongation at $68^{\circ} \mathrm{C}$ for $30 \mathrm{~s}$, and a final extension at $68^{\circ} \mathrm{C}$ for $10 \mathrm{~min}$.

\section{Illumina Hiseq 2500 sequencing}

The amplicons were extracted from 2\% agarose gels and purified using the AxyPrep DNA Gel Extraction Kit (Axygen Biosciences, Union City, CA, USA) according to the manufacturer's instructions and quantified using QuantiFluor-ST (Promega, USA). Purified amplicons were pooled in equimolar and paired-end sequenced $(2 \times 250)$ on an Illumina platform according to the standard protocols.

\section{Statistical and bioinformatics analysis Quality control and reads assembly}

Raw data containing adapters or low quality reads would affect the following assembly and analysis. Thus, to get high quality clean reads, quality control and reads assembly were carried out according to the Zhang et al' study [76] and the following rules: 1) Removing reads containing more than $10 \%$ of unknown nucleotides $(\mathrm{N})$; 2) Removing reads containing less than $80 \%$ of bases with quality $(\mathrm{Q}$-value $)>20$. Paired end clean reads were merged as raw tags using Fast Length Adjustment of Short reads (FLASH) [48] (Version 1.2.11) with a minimum overlap of $10 \mathrm{bp}$ and mismatch error rates of $2 \%$. Noisy sequences of raw tags were filtered by Quantitative Insights Into Microbial Ecology (QIIME) [17] (Version 1.9.1) pipeline under specific filtering conditions [11] to obtain the high-quality clean tags. Clean tags were searched against the reference database (http:// drive5.com/uchime/uchime_download.html) to perform reference-based chimera checking using UCHIME algorithm (http://www.drive5.com/usearch/manual/uchime algo.html). The chimera sequences were finally removed, and the effective tags were generated for further analysis.

\section{OTU cluster and taxonomy classification}

The effective tags were clustered into operational taxonomic units (OTUs) of $\geq 97 \%$ similarity using UPARSE [24] pipeline. The tag sequence with the highest abundance was selected as representative sequence within each cluster. Taxonomic classification of the representative sequence for each OTU was performed using the Ribosomal Database Project classifier (http://rdp.cme. msu.edu/). Each prokaryotic OTU was aligned against SILVA 16S rRNA database (https://www.arb-silva.de/). Each eukaryotic OTU was aligned against the SILVA 18S rRNA database or ITS2 database (http://its2. bioapps.biozentrum.uni-wuerzburg.de/). For prokaryotic OTU analysis, sequences having the best match with eukaryotes (i.e., chloroplasts and mitochondria) were excluded from the OTU table and downstream analyses.

\section{Alpha diversity and beta diversity analysis}

The coverage percentage was estimated by Good's method [31]. The abundance-based coverage estimator (ACE), bias-corrected Chao1 richness estimator, and the Shannon and Simpson diversity indices were also calculated in QIIME. OTU rarefaction curve and Rank abundance curves were plotted in QIIME. In the beta diversity analyses, principal coordinate analyses (PCoA) 
utilizing the unweighted UniFrac distances, were calculated using the $\mathrm{R}$ package, and dendrograms were composed using the unweighted pair group method with arithmetic mean (UPGMA) algorithm in BioNumerics to determine the similarity among the samples.

\section{Predicted functional analysis for microbial communities}

Tax4Fun and FUNGuild analysis were conducted to predict microbial functional profiling. Tax4Fun is an opensource $\mathrm{R}$ package that predicts the functional capabilities of prokaryotic communities based on 16SrRNA data sets [5]. And heat map of the Kyoto Encyclopedia of Genes and Genomes (KEGG) level-2 functional pathways was carried out by R package. FUNGuild is a novel tool to comprehensively examine the fungal communities from an ecological perspective [55].

\section{Statistical analysis}

Data were analyzed using the SPSS 19.0 statistical software packages. All values are presented as the means \pm standard deviation (mean $\pm \mathrm{SD}$ ). The level of statistical significance was determined using $\mathrm{T}$-test and Duncan Multiple Comparisons Test. Community composition comparison between two groups was calculated by $\mathrm{T}$ test. Community richness and diversity comparisons among groups were computed by Duncan Multiple Comparisons Test. The statistical significance was set at $p<0.05$.

\section{Abbreviations}

ITS: Internal transcribed spacer; KEGG: Kyoto Encyclopedia of Genes and Genomes; OTU: Operational Taxonomic Units; PCoA: Principal Coordinate Analyses; UPGMA: Unweighted Pair Group Method With Arithmetic Mean

\section{Acknowledgments}

The authors would like to thank Yellow Sea Fisheries Research Institute, Chinese Academy of Fishery Sciences for equipment support, and the authors are highly appreciative of Feiyue Chi for the sampling.

\section{Authors' contributions}

ZL designed and performed the experiments, analyzed the data, and drafted the manuscript. FL performed sample collection, helped design experiments, analyzed the data and drafted the manuscript. WW performed sample collection and PCR amplification. PZ performed DNA extraction and PCR amplification. TS and FW performed sample collection and analyzed part of the data. HK helped draft the manuscript. All authors read and approved the final manuscript.

\section{Funding}

This study was financially supported by Central Public-interest Scientific Institution Basal Research Fund, YSFRI, CAFS (NO. 20603022018022), National Key R\&D Program of China (2018YFD0900305), China Agriculture Research System (CARS-50), Key Laboratory of Sustainable Development of Marine Fisheries Open Project Fund, Ministry of Agriculture and Rural Affairs, and Projects of International Exchange and Cooperation in Agriculture, Ministry of Agriculture and Rural Affairs of China, Technology and Innovation Cooperation in Aquaculture with Tropical Countries along the Belt and Road. The funding agencies had no role in the design of this study, in the collection, analysis, or interpretation of the data, or in the writing of this manuscript.

\section{Availability of data and materials}

We confirm we have included a statement specifying the local, national or international guidelines and legislation and the required or appropriate permissions and/or licences for the study. Sequence data of this project have been deposited in the Sequence Read Archive (SRA) of the National Center for Biotechnology Information (NCBI) under the accession number PRJNA566062.

Ethics approval and consent to participate Not Applicable.

Consent for publication

Not Applicable.

\section{Competing interests}

The authors declare that they have no competing interests.

\section{Author details}

1Key Laboratory of Sustainable Development of Marine Fisheries, Ministry of Agriculture and Rural Affairs, Yellow Sea Fisheries Research Institute, Chinese Academy of Fishery Sciences, Qingdao, China. ${ }^{2}$ Laboratory for Marine Fisheries Science and Food Production Processes, Qingdao National Laboratory for Marine Science and Technology, Qingdao, China. ${ }^{3}$ College of Science and Engineering, Flinders University, Adelaide, Australia.

Received: 8 August 2019 Accepted: 29 September 2019

Published online: 15 October 2019

\section{References}

1. Aires T, Moalic Y, Serrao EA, Arnaud-Haond S. Hologenome theory supported by cooccurrence networks of species-specific bacterial communities in siphonous algae (Caulerpa). FEMS Microbiol Ecol. 2015;91(7): 409-17.

2. Aires $T$, Serrão $E A$, Kendrick $G$, Duarte $C M$, Arnaud-Haond $S$. Invasion is a community affair: clandestine followers in the bacterial community associated to green algae, Caulerpa racemosa, track the invasion source. PLoS One. 2013;8:e68429.

3. Armstrong E, Yan L, Boyd KG, Wright PC, Burgess JG. The symbiotic role of marine microbes on living surfaces. Hydrobiologia. 2001;461:37-40.

4. Arnold AE, Mejia LC, Kyllo D, Rojas El, Maynard Z, Robbins N, Herre EA. Fungal endophytes limit pathogen damage in a tropical tree. Proc Natl Acad Sci U S A. 2003;100(26):15649-54.

5. Aßhauer KP, Wemheuer B, Daniel R, Meinicke P. Tax4Fun: predicting functional profiles from metagenomic $16 \mathrm{~S}$ rRNA data. Bioinformatics. 2015; 31(17):2882-4

6. Barott KL, Rodriguez-Brito B, Janouškovec J, Marhaver KL, Smith JE, Keeling P. Rohwer FL. Microbial diversity associated with four functional groups of benthic reef algae and the reef-building coral Montastraea annularis. Environ Microbiol. 2011;13(5):1192-204

7. Bengtsson MM, Øvreås L. Planctomycetes dominate biofilms on surfaces of the kelp Laminaria hyperborea. BMC Microbiol. 2010;10:261.

8. Bennett JA, Maherali H, Reinhart KO, Lekberg Y, Hart MM, Klironomos J. Plant-soil feedbacks and mycorrhizal type influence temperate forest population dynamics. Science. 2017;355(6321):181-4.

9. Bertrand EM, McCrow JP, Moustafa A, Zheng H, McQuaid JB, Delmont TO, Post AF, Sipler RE, Spackeen JL, Xu K, Bronk DA, Hutchins DA, Allen AE. Phytoplankton-bacterial interactions mediate micronutrient colimitation at the coastal Antarctic Sea ice edge. Proc Natl Acad Sci U S A. 2015;112:9938-43.

10. Biebl H, Pukall R, Lünsdorf H, Schulz S, Tindall BJ AM, Wagner-Döbler I. Description of Labrenzia alexandrii gen. nov., sp. nov., a novel alphaproteobacterium containing bacteriochlorophyll a, and a proposal for reclassification of Stappia aggregate as Labrenzia aggregata comb. nov., of Stappia marina as Labrenzia marina comb. nov. and of Stappia alba as Labrenzia alba comb. nov., and emended descriptions of the genera Pannonibacter, Stappiaand and Roseibium, and of the species Roseibium denhamense and Roseibium hamelinense. International Journal of Systematic and Evolutionary Microbiology. 2007;57:1095-107.

11. Bokulich NA, Subramanian S, Faith JJ, Gevers D, Gordon JI, Knight R, Mills DA, Caporaso JG. Quality-filtering vastly improves diversity estimates from Illumina amplicon sequencing. Nat Methods. 2013;10(1):57-9. 
12. Bondoso J, Balagué V, Gasol JM, Lage OM. Community composition of the Planctomycetes associated with different macroalgae. FEMS Microbiol Ecol. 2014;88(3):445-56.

13. Burgess JG, Boyd KG, Armstrong E, Jiang Z, Yan L, Berggren M, May U, Pisacane T, Granmo A, Adams DR. The development of a marine natural product-based antifouling paint. Biofouling. 2003;19:197-205.

14. Burgess JG, Jordan EM, Bregu M, Mearns-Spragg A, Boyd KG. Microbial antagonism: a neglected avenue of natural products research. J Biotechnol. 1999;35:27-32.

15. Burke C, Steinberg P, Rusch D, Kjelleberg S, Thomas T. Bacterial community assembly based on functional genes rather than species. Proc Natl Acad Sci U S A. $2011 \mathrm{a} ; 108(34): 14288-93$.

16. Burke C, Thomas T, Lewis M, Steinberg P, Kjelleberg S. Composition, uniqueness and variability of the epiphytic bacterial community of the green alga Ulva australis. The ISME Journal. 2011b;5:590-600.

17. Caporaso JG, Kuczynski J, Stombaugh J, Bittinger K, Bushman FD, Costello EK, Fierer N, Peña AG, Goodrich JK, Gordon Jl, Huttley GA, Kelley ST, Knights D, Koenig JE, Ley RE, Lozupone CA, McDonald D, Muegge BD, Pirrung M, Reeder J, Sevinsky JR, Turnbaugh PJ, Walters WA, Widmann J, Yatsunenko T, Zaneveld J, Knight R. QIIME allows analysis of high-throughput community sequencing data. Nat Methods. 2010;7(5):335-6.

18. Coppejans E, Beeckman T. Caulerpa (Chlorophyta, Caulerpales) from the Kenyan coast. Nova Hedwigia. 1990;50:111-25.

19. Cude WN, Mooney J, Tavanaei AA, Hadden MK, Frank AM, Gulvik CA, May AL, Buchan A. Production of the antimicrobial secondary metabolite indigoidine contributes to competitive surface colonization by the marine Roseobacter Phaeobacter sp. strain Y4l. Appl Environ Microbiol. 2012;78(14):4771-80.

20. de Mesquita MMF, Crapez MAC, Teixeira VL, Cavalcanti DN. Potential interactions bacteria-brown algae. J Appl Phycol. 2019;31(2):867-83.

21. Debbab A, Aly AH, Lin WH, Proksch P. Bioactive compounds from marine bacteria and fungi. Microb Biotechnol. 2010;3(5):544-63.

22. Delbridge L, Coulburn J, Fagerberg W, Tisa LS. Community profiles of bacterial endosymbionts in four species of Caulerpa. Symbiosis. 2004; 37:335-44.

23. Dobretsov S, Dahms HU, Qian PY. Inhibition of biofouling by marine microorganisms and their metabolites. Biofouling. 2006:22(1):43-54

24. Edgar RC. UPARSE: highly accurate OTU sequences from microbial amplicon reads. Nat Methods. 2013;10:996-8.

25. Egan S, Harder T, Burke C, Steinberg P, Kjelleberg S, Thomas T. The seaweed holobiont: understanding seaweed-bacteria interactions. FEMS Microbiol Rev. 2013;37:462-76

26. El Bour M, Ali Al-B, Ktari L. Seaweeds epibionts: biodiversity and potential bioactivities. In: Méndez-Vilas A (ed.) Microbial pathogens and strategies for combating them: science, technology and education. Formatex Research Center, Badajoz, Spain. 2013; 1298-1306.

27. Engel $\mathrm{S}$, Jensen PR, Fenical W. Chemical ecology of marine microbial defense. J Chem Ecol. 2002;28(10):1971-85.

28. Faria M, Bordin N, Kizina J, Harder J, Devos D, Lage OM. Planctomycetes, attached to algal surfaces: insight into their genomes. Genomics. 2018; 110(5):231-8.

29. Fernández-Gómez B, Richter M, Schüler M, Pinhassi J, Acinas SG, González JM, Pedrós-Alió C. Ecology of marine Bacteroidetes: a comparative genomics approach. The ISME Journal. 2013;7(5):1026-37.

30. Goecke F, Thiel V, Wiese J, Labes A, Imhoff JF. Algae as an important environment for bacteria - phylogenetic relationships among new bacterial species isolated from algae. Phycologia. 2013;52(1):14-24.

31. Good IJ. The population frequencies of species and the estimation of population parameters. Biometrika. 1953;40(3-4):237-64.

32. Gromek SM, Suria AM, Fullmer MS, Garcia JL, Gogarten JP, Nyholm SV, Balunas MJ. Leisingera sp. JC1, a bacterial isolate from hawaiian bobtail squid eggs, produces indigoidine and differentially inhibits vibrios. Frontiers in. Microbiology. 2016;7:1342.

33. Grossart HP, Kiørboe T, Tang K, Ploug H. Bacterial colonization of particles: growth and interactions. Appl Environ Microbiol. 2003;69(6):3500-9.

34. Harvey JBJ, Goff LJ. Genetic covariation of the marine fungal symbiont Haloguignar diairritans (Ascomycota, Pezizomycotina) with its algal hosts Cystoseira and Halidrys (Phaeophyceae, Fucales) along the west coast of North America. Fungal Biology. 2010;114:82-95.

35. Hollants J, Leroux O, Leliaert F, Decleyre H, De Clerck O, Willems A. Who is in there? Exploration of endophytic bacteria within the siphonous green seaweed Bryopsis (Bryopsidales, Chlorophyta). PLoS One. 2011;6(10):e26458.
36. Horstmann U. Cultivation of the green alga, Caulerpa racemosa, in tropical waters and some aspects of its physiological ecology. Aquaculture. 1983;32:361-71.

37. Huang SY, Hadfield MG. Composition and density of bacterial biofilms determine larval settlement of the polychaete Hydroides elegans. Mar Ecol Prog Ser. 2003;260:161-72.

38. Jones KL, Mikulski CM, Barnhorst A, Doucette GJ. Comparative analysis of bacterioplankton assemblages from Karenia brevis bloom and nonbloom water on the West Florida shelf (Gulf of Mexico, USA) using 16S rRNA gene clone libraries. FEMS Microbiol Ecol. 2010;73:468-85.

39. Lachnit T, Blümel M, Imhoff JJF, Wahl M. Specific epibacterial communities on macroalgae: phylogeny matters more than habitat. Aquat Biol. 2009;5:181-6.

40. Lachnit T, Meske D, Wahl M, Harder T, Schmitz R. Epibacterial community patterns on marine macroalgae are host-specific but temporally variable. Environ Microbiol. 2011;13:655-65.

41. Lachnit T, Wahl M, Harder T. Isolated thallus-associated compounds from the macroalga Fucus vesiculosus mediate bacterial surface colonization in the field similar to that on the natural alga. Biofouling. 2010;26(3):247-55.

42. Lage OM, Bondoso J. Planctomycetes diversity associated with macroalgae. FEMS Microbiol Ecol. 2011;78:366-75.

43. Leonard G. Marine fungi: their ecology and molecular diversity. Annu Rev Mar Sci. 2012;4(1):495-522

44. Lewin RA. Saprospira grandis: a flexibacterium that can catch bacterial prey by "Ixotrophy". Microb Ecol. 1997;34(3):232-6.

45. Li JM, Li RH, Li J. Current research scenario for microcystins biodegradation - a review on fundamental knowledge, application prospects and challenges. Sci Total Environ. 2017:595:615-32.

46. Longford SR, Tujula NA, Crocetti GR, Holmes AJ, Holmström C, Kjelleberg S, Steinberg PD, Taylor MW. Comparisons of diversity of bacterial communities associated with three sessile marine eukaryotes. Aquat Microb Ecol. 2007; 48(3):217-29.

47. Luo HW, Moran MA. Evolutionary ecology of the marine roseobacter clade. Microbiol Mol Biol Rev. 2014;78(4):573-87.

48. Magoč T, Salzberg SL. FLASH: fast length adjustment of short reads to improve genome assemblies. Bioinformatics. 2011;27(21):2957-63.

49. Mary A, Mary V, Lorella A, Matias J. Rediscovery of naturally occurring seagrape Caulerpa lentillifera from the Gulf of Mannar and its mariculture. Curr Sci. 2009:97(10):1418-20.

50. Menez EG, Calumpong HP. The genus Caulerpa from Central Visayas, Philippines. Washington: Smithsonian Institution Press; 1982.

51. Meusnier I, Olsen JL, Stam WT, Destombe C, Valero M. Phylogenetic analyses of Caulerpa taxifolia (Chlorophyta) and of its associated bacterial microflora provide clues to the origin of the Mediterranean introduction. Mol Ecol. 2001:10(4):931-46.

52. Michael V, Frank O, Bartling P, Scheuner C, Göker M, Brinkmann H, Petersen J. Biofilm plasmids with a rhamnose operon are widely distributed determinants of the 'swim-or-stick' lifestyle in roseobacters. The ISME Journal. 2016:10(10):2498-513.

53. Nagappan T, Vairappan CS. Nutritional and bioactive properties of three edible species of green algae, genus Caulerpa (Caulerpaceae). J Appl Phycol. 2014;26:1019-27.

54. Nash AK, Auchtung TA, Wong MC, Smith DP, Gesell JR, Ross MC, Stewart CJ, Metcalf GA, Muzny DM, Gibbs RA, Ajami NJ, Petrosino JF. The gut mycobiome of the human microbiome project healthy cohort. Microbiome. 2017:5(1):153.

55. Nguyen NH, Song Z, Bates ST, Branco S, Tedersoo L, Menke J, Schilling JS, Kennedy PG. FUNGuild: an open annotation tool for parsing fungal community datasets by ecological guild. Fungal Ecol. 2016;20(1):241-8.

56. Patel P, Callow ME, Joint I, Callow JA. Specificity in larval settlementmodifying response of bacterial biofilms towards zoospores of the marine alga Enteromorpha. Environ Microbiol. 2003;5(5):338-49.

57. Penesyan A, Kjelleberg S, Egan S. Development of novel drugs from marine surface associated microorganisms. Marine Drugs. 2010:8(3):438-59.

58. Phillips JA, Conacher C, Horrocks J. Marine macroalgae from the Gulf of Carpentaria, tropical northern Australia. Aust Syst Bot. 1999:12:449-78.

59. Potin P. Intimate Associations Between Epiphytes, Endophytes, and Parasites of Seaweeds. In: Wiencke C., Bischof K. (eds), Seaweed Biology, Ecological Studies, vol 219. Springer, Berlin, Heidelberg; 2012.

60. Riedel T, Teshima H, Petersen J, Fiebig A, Davenport K, Dalingault H, Erkkila T, Gu W, Munk C, Xu Y, Chen A, Pati A, Ivanova N, Goodwin LA, Chain P, 
Detter JC, Rohde M, Gronow S, Kyrpides NC, Woyke T, Göker M, Brinkhoff T, Klenk H-P. Genome sequence of the Leisingera aquimarina type strain (DSM $24565^{\top}$ ), a member of the marine Roseobacter clade rich in extrachromosomal elements. Stand Genomic Sci. 2013;8(3):389-402.

61. Salaün S, La Barre S, Dos Santos-Goncalvez M, Potin P, Haras D, Bazire A. Influence of exudates of the kelp Laminaria digitata on biofilm formation of associated and exogenous bacterial epiphytes. Microb Ecol. 2012;64(2):359-69.

62. Scherer PI, Millard AD, Miller A, Schoen R, Raeder U, Geist J, Zwirglmaier K. Temporal dynamics of the microbial community composition with a focus on toxic cyanobacteria and toxin presence during harmful algal blooms in two south German lakes. Front Microbiol. 2017;8:2387.

63. Singh RP, Reddy CRK. Seaweed-microbial interactions: key functions of seaweed-associated bacteria. FEMS Microbiol Ecol. 2014;88(2):213-30.

64. Suryanarayanan TS. Fungal Endosymbionts of Seaweeds. In: Raghukumar C. (eds) Biology of Marine Fungi. Progress in Molecular and Subcellular Biology, vol 53. Springer, Berlin, Heidelberg; 2012.

65. Suryanarayanan TS, Venkatachalam A, Thirunavukkarasu N, Ravishankar JP, Doble M, Venkatachalam G. Internal mycobiota of marine macroalgae from the Tamilnadu coast: distribution, diversity and biotechnological potential. Bot Mar. 2010;53:457-68.

66. Titlyanov EA, Titlyanova TV. Seaweed cultivation: methods and problems. Russ J Mar Biol. 2010;36:227-42

67. Titlyanov EA, Titlyanova TV, Pham VH. Stocks and the use of economic marine macrophytes of Vietnam. Russ J Mar Biol. 2012;38(4):285-98.

68. Tujula NA, Crocetti GR, Burke C, Thomas T, Holmström C, Kjelleberg S. Variability and abundance of the epiphytic bacterial community associated with a green marine Ulvacean alga. The ISME Journal. 2010;4(2):301-11.

69. Turner TR, James EK, Poole PS. The plant microbiome. Genome Biol. 2013; 14(6):209-18.

70. Vairappan CS. Seasonal occurrences of epiphytic algae on the commercially cultivated red alga Kappaphycus Alvarezii (Solieriaceae, Gigartinales, Rhodophyta). J Appl Phycol. 2006;18:611-7.

71. Wagner BL, Lewis LC. Colonization corn, Zea mays, by the endopathogenic fungus Beauveria bassian. Appl Environ Microbiol. 2000;66(8):3468-73.

72. Wegner CE, Richter-Heitmann T, Klindworth A, Klockow C, Richter M, Achstetter T, Glöckner FO, Harder J. Expression of sulfatases in Rhodopirellula baltica and the diversity of sulfatases in the genus Rhodopirellula. Mar Genomics. 2013;9:51-61.

73. White JF Jr, Torres MS. Is plant endophyte-mediated defensive mutualism the result of oxidative stress protection? Physiol Plant. 2010;138(4):440-6.

74. Wichard T, Beemelmanns $C$. Role of chemical mediators in aquatic interactions across the prokaryote-eukaryote boundary. J Chem Ecol. 2018; 44:1008-21.

75. Woodhouse JN, Kinsela AS, Collins RN, Bowling LC, Honeyman GL, Holliday $\mathrm{JK}$, Neilan BA. Microbial communities reflect temporal changes in cyanobacterial composition in a shallow ephemeral freshwater lake. The ISME Journal. 2016;10:1337-51.

76. Zhang HN, Feng J, Chen SN, Zhao ZF, Li BQ, Wang Y, Jia JY, Li SL, Wang Y, Yan MM, Lu KY, Hao HY. Geographical patterns of nirS gene abundance and nirs-type denitrifying bacterial community associated with activated sludge from different wastewater treatment plants. Microb Ecol. 2019;77(2):304-16.

77. Zozaya-Valdes E, Egan S, Thomas T. A comprehensive analysis of the microbial communities of healthy and diseased marine macroalgae and the detection of known and potential bacterial pathogens. Front Microbiol. 2015;6(146):1-9.

78. Zuccaro A, Schoch CL, Spatafora JW, Kohlmeyer J, Draeger S, Mitchell JI. Detection and identification of fungi intimately associated with the brown seaweed Fucus serratus. Appl Environ Microbiol. 2008;74:931-41.

79. Zuccaro A, Schulz B, Mitchell Jl. Molecular detection of ascomycetes associated with Fucus serratus. Mycol Res. 2003;107:1451-66.

\section{Publisher's Note}

Springer Nature remains neutral with regard to jurisdictional claims in published maps and institutional affiliations.

Ready to submit your research? Choose BMC and benefit from:

- fast, convenient online submission

- thorough peer review by experienced researchers in your field

- rapid publication on acceptance

- support for research data, including large and complex data types

- gold Open Access which fosters wider collaboration and increased citations

- maximum visibility for your research: over $100 \mathrm{M}$ website views per year

At BMC, research is always in progress.

Learn more biomedcentral.com/submissions 